\title{
Cardiac fibroblasts, fibrosis and extracellular matrix remodeling in heart disease
}

\author{
Dong Fan ${ }^{1}$, Abhijit Takawale ${ }^{1}$, Jiwon Lee ${ }^{1}$ and Zamaneh Kassiri ${ }^{12^{*}}$
}

\begin{abstract}
Fibroblasts comprise the largest cell population in the myocardium. In heart disease, the number of fibroblasts is increased either by replication of the resident myocardial fibroblasts, migration and transformation of circulating bone marrow cells, or by transformation of endothelial/epithelial cells into fibroblasts and myofibroblasts. The primary function of fibroblasts is to produce structural proteins that comprise the extracellular matrix (ECM). This can be a constructive process; however, hyperactivity of cardiac fibroblasts can result in excess production and deposition of ECM proteins in the myocardium, known as fibrosis, with adverse effects on cardiac structure and function. In addition to being the primary source of ECM proteins, fibroblasts produce a number of cytokines, peptides, and enzymes among which matrix metalloproteinases (MMPs) and their inhibitors, tissue inhibitor of metalloproteinases (TIMPs), directly impact the ECM turnover and homeostasis. Function of fibroblasts can also in turn be regulated by MMPs and TIMPs. In this review article, we will focus on the function of cardiac fibroblasts in the context of ECM formation, homeostasis and remodeling in the heart. We will discuss the origins and multiple roles of cardiac fibroblasts in myocardial remodeling in different types of heart disease in patients and in animal models. We will further provide an overview of what we have learned from experimental animal models and genetically modified mice with altered expression of ECM regulatory proteins, MMPs and TIMPS.
\end{abstract}

Keywords: Cardiac fibroblast, Matrix metalloproteinases, Tissue inhibitor of metalloproteinases, Extracellular matrix remodeling, Heart disease

\section{Review}

\section{Cardiac fibroblasts}

Myocardium is comprised of a number of cell types, cardiomyocytes, cardiofibroblasts, endothelial cells and smooth muscle cells. Cardiac fibroblasts (CFBs) have the highest cell population in the myocardium, accounting for about two-thirds of the cells, while cardiomyocytes constitute about two-thirds of the myocardial tissue volume [1], although this ratio may vary in different species [2]. A number of excellent reviews have discussed the contribution of the contractile proteins and the molecules involved in intracellular calcium handing in cardiomyocytes in cardiac pathologies [3-5]. In this review, we will provide an overview of the literature on the role of CFBs in the context of extracellular matrix (ECM)

\footnotetext{
* Correspondence: z.kassiri@ualberta.ca

1Department of Physiology, University of Alberta, Edmonton, AB T6G 2S2, Canada

${ }^{2}$ Mazankowski Alberta Heart Institute/Cardiovascular Research Center, University of Alberta, Edmonton, AB T6G 2S2, Canada
}

remodeling and its contribution to development and progression of heart disease. Fibroblasts (FBs) are cells of mesenchymal origin and are present in every tissue in the body [2,6]. Morphologically, FBs are flat and spindleshaped with multiple projecting processes. In the myocardium, CFBs are unique among other cell types in that they lack a basement membrane. Although historically FBs were considered a homogeneous cell population, it has become increasingly clear that FBs from different tissues have different properties and functions [2,7]. In this review we will focus our discussion on CFBs, although some of the discussed properties and functions could also apply to FBs from other tissue sources.

A number of cell surface markers have been identified for FBs and CFBs, but over time their specificity to these cells has been challenged. Vimentin, a protein that is present in the intermediate filaments of FBs, has been the most widely used FB marker - and although it is also expressed in other cell types such as endothelial cells [8] and myoepithelial cells [9], due to

\section{Biomed Central}


morphological differences among these cell types, vimentin remains a reliable marker for identifying FBs [10]. Discoidin domain receptor (DDR) 2 was discovered as a specific marker for CFBs [1,2,11]. DDR1 and DDR2 are collagen receptors [12,13], a family of protein tyrosine kinases involved in a variety of cellular functions such as growth, migration and differentiation [14]. DDR1 is expressed mainly in epithelial cells, whereas DDR2 is expressed in mesenchymal cells [15]. DDR2 was detected in rat and mouse heart [16], and has been considered to be more specific than vimentin for CFBs since it is not expressed in cardiomyocytes or cardiac endothelial cells [11]; however, it is also expressed on specific bone-marrow-derived cells, fibrocytes [17], leukocytes, vascular smooth muscle cells [18,19], and corneal epithelial and endothelial cells [20]. Another FB marker is fibroblast-specific protein 1, a filamentassociated calcium-binding protein in FBs [21]; however, fibroblast-specific protein 1 has also been found to be expressed in leukocytes and a number of cancer cells [22].

\section{Myofibroblasts}

In response to appropriate stimuli, most commonly myocardial injury, CFBs can differentiate into myofibroblasts (myoFBs), which are more mobile and contractile with a greater synthetic ability to produce ECM proteins [23]. MyoFBs, originally identified and named by Gabbiani in 1971 [24], are not found in healthy myocardium and only appear following cardiac injury [25]. Similar to CFBs, cardiac myoFBs are nonexcitable cells, but express a number of smooth muscle cell markers that are not typically expressed in quiescent CFBs, such as alpha smooth muscle actin ( $\alpha \mathrm{SMA}$ ) [26], smooth muscle myosin heavy chain, vinculin, paxillin, and tensin [27]. The internal microfilmanents in the myoFBs are connected to the extracellular fibronectin domains via specialized adhesion complexes called fibronexus. This allows the myoFBs to exert a contractile force on the surrounding ECM [28]. MyoFBs are highly responsive to chemokines released at the site of injury. This is the main mechanism that mediates migration of FBs to the site of injury. In addition, myoFBs themselves produce and secrete a number of cytokines (for example, IL-1 $\alpha$, IL-1 $\beta$, IL-6, IL-10 and TNF $\alpha$ ), which in turn help to maintain the inflammatory response to injury [25].

Cardiac injury triggers CFBs to be differentiated to myoFBs, which have a stronger ability to produce ECM proteins. MyoFB have been demonstrated to play a key role in reparative fibrosis in the infarcted heart [29], and to be associated with hypertrophic fibrotic scars in various injury models. Differentiation from FB to myoFB is promoted by transforming growth factor beta (TGF $\beta$ ), cytokines, the ECM, and other growth factors [30,31].
TGF $\beta$ induces the transdifferentiation of CFBs into myoFBs and increases collagen expression [23], whereas IL-1 $\beta$ inhibits differentiation of CFBs by preventing the expression of $\alpha$ SMA and other contractile proteins in these cells [25]. In vitro, $\alpha$ SMA expression levels in cultured CFBs are increased by passaging, and after the third passage CFBs are believed to become myoFBs [25] with elevated TGF $\beta$ expression such that stimulation with exogenous TGF $\beta$ could not further increase collagen production in these cells [23]. Transformation of CFBs to myoFBs shifts the balance in ECM turnover, increasing synthesis and accumulation of fibrotic depositions that can replace the myocytes and/or interrupt the myocyte-myocyte interactions in the myocardium leading to overall impairment of cardiac function.

\section{Origins of cardiac fibroblasts}

CFBs are derived from mesenchymal cells. During heart development, epicardial cells formed by migration of proepicardial cells over the embryonic heart undergo epithelial-to-mesenchymal transformation and subsequently differentiate into FBs [32]. This transition is induced primarily by periostin [33] and TGF $\beta$ [34]. However, epicardial cells do not constitute all of the FBs in the heart. In principle, they only contribute to the FBs in the cardiac interstitium [35] and fibrous annulus $[36,37]$. The annulus is an electrically inert structure that forms the isolating barrier between the atrial and ventricular tissues necessary for normal sequential activation of the heart. The FBs in the atrioventricular valve leaflets are primarily derived from the endocardium [38]. After the completion of embryonic development, the epicardium-derived and endocardium-derived cells become quiescent.

Injury to the heart can trigger amplification of resident CFBs, transformation of endothelial or epithelial cells to FBs, or recruitment of hematopoietic cells originating from the bone marrow to the site of injury and their transformation into CFBs and myoFBs (Figure 1). Myocardial fibrosis in response to cardiac pressure overload is a characteristic feature of this disease and has been reported to result from proliferation of resident CFBs [39] as well as transformation of endothelial cells to mesenchymal cells leading to generation of CFBs and myoFBs [40,41]. Endothelial-to-mesenchymal transformation can be induced by TGF $\beta$ in a Smad-dependent fashion during cardiac fibrosis, while bone morphogenic protein 7 blocks this process and could serve as an antifibrotic factor [40]. A very recent study has reported that suppression of receptor kinase Tie-1, but not Tie-2, promotes endothelial-to-mesenchymal transformation in human endothelial cells [42]. In addition, Notchmediated epithelial-to-mesenchymal transformation has also been reported to lead to CFB proliferation in 


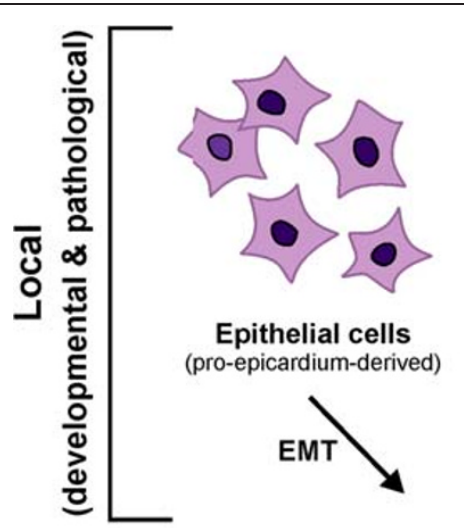

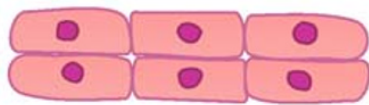

Endothelial cells

(endocardium-derived)

EndMT

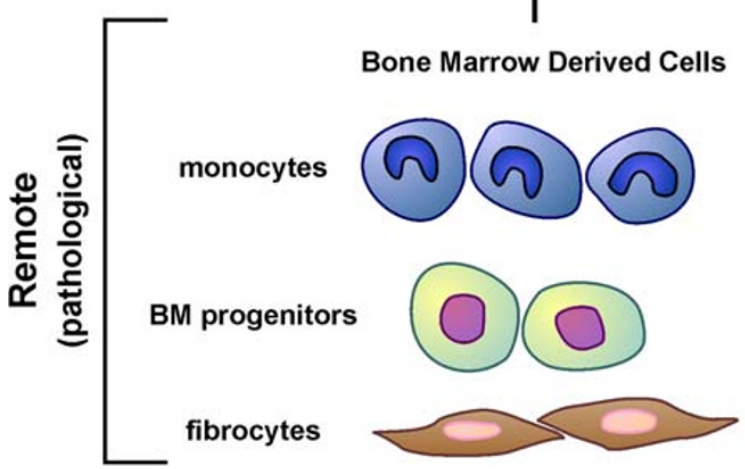

Figure 1 Origin of cardiac fibroblasts during development and disease. During development, epicardium-derived cells undergo epithelialmesenchymal transformation (EMT), while endothelial cells (from the endocardium) can undergo endothelial-mesenchymal (EndMT) and transform to cardiac fibroblasts. Following myocardial injury, bone marrow (BM)-derived cells (monocytes, BM progenitors and fibrocytes) can be recruited to the site of injury and transformed to cardiac fibroblasts. This can occur in addition to EMT and/or EndMT.

myocardial infarction (MI) as well as in aortic constriction [43].

Bone marrow-derived cells and circulating blood cells such as monocytes and fibrocytes are another source of CFBs in response to injury [6]. Monocytes have been proposed as a potential source of CFBs in pathological fibrosis in ischemia-reperfusion injury through elevated monocyte chemoattractant protein-1, which promoted the uptake of hematologic monocytes [44], and MI [45,46]. Fibrocytes, circulating FB progenitor cells, originate from the hematopoietic stem cells in the bone marrow and display phenotypic similarities to other leukocytes such as CD14 expressed by monocytes [47]. Following MI, bonemarrow-derived cells were found to constitute a large number of CFBs and myoFBs in the infarct area contributing to infarct formation [45,48]. In addition, bone-marrow-derived cells were found to constitute more than $60 \%$ of the CFBs and myoFBs in an experimental autoimmune myocarditis model [49], and about $30 \%$ of CFBs and myoFBs in cardiac pressure overload [40]. CCR2, a chemokine receptor that is expressed on bone marrow cells, has been shown to be critical in recruitment of bone marrow cells to the heart during disease since CCR2 deficiency prevented angiotensin-II-induced accumulation of bone-marrowderived FB precursors (fibrocytes) in the myocardium and cardiac fibrosis [50]. Perivascular cells, such as pericytes, have been shown to differentiate into collagen-producing FBs in the kidney [51] and in the retina in vitro [52], but the contribution of these cells in formation of CFBs has not yet been determined [6]. In summary, the origin of CFBs during development is different from that during disease, which 
could explain the different functions and properties of CFBs during development, health and disease.

\section{Functions of cardiac fibroblasts}

CFBs are involved in many aspects of cardiac functions, such as homeostasis and remodeling of the cardiac ECM, cell-cell communication with cardiomyocytes, electrical activity, production of growth factors and cytokines, and intercellular signaling with other CFBs, endothelial or smooth muscle cells that can impact cellular events such as angiogenesis, cell proliferation, cardiomyocyte hypertrophy or apoptosis (Figure 2). FBs can also be reprogrammed into different cell types, such as pluripotent stem cells [53], myoblasts [54], neurons [55]. Recently, it has been reported that FBs can be reprogramed to contracting cardiac-like myocytes cells by expressing developmental transcription factors, MEF2, HAND2, GATA4 and TBX5 [56,57], or by treatment with a combination of miRNAs (miRNAs 1, 133, 208 and 499) [58]. As such, CFBs are critical in maintaining normal cardiac structure, function, biochemical and electrical features of the heart, and CFBs also play a key role during pathological remodeling of the heart. CFBs are conductors with a high membrane resistance [59] and electrically separate the atria and the ventricle, by forming the fibrotic annulus, to ensure proper contraction of the heart [36]. CFBs are connected with cardiomyocytes via gap junctions, particularly connexins (Cx40, Cx43, and Cx45), which is essential in maintaining an optimal electrical conduction in the heart $[10,60]$. Another major function of CFBs is to synthesize a

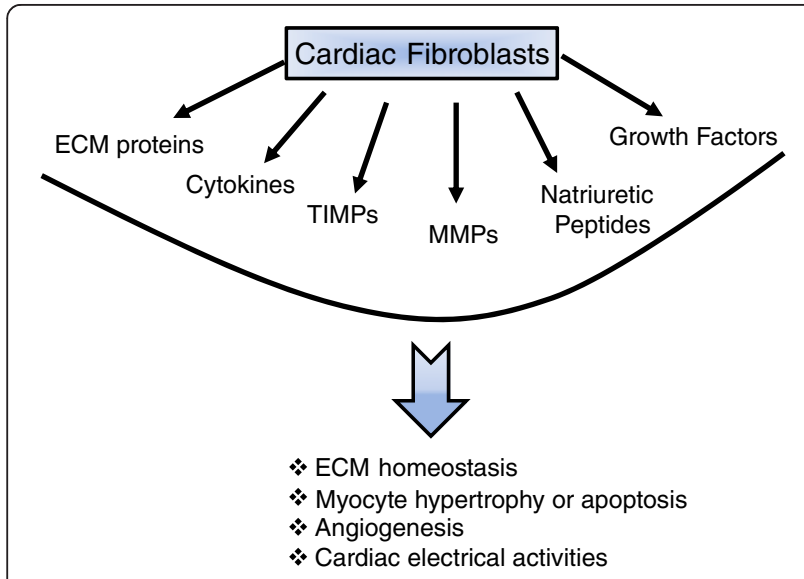

Figure 2 Pluripotent cardiac fibroblasts impact different aspects of cardiac structure and function. Cardiac fibroblasts can produce a number of active peptides (for example, cytokines, growth factors, peptides), extracellular matrix (ECM) proteins (collagens, elastin, fibronectin, and so forth), and ECM-regulatory proteins, matrix metalloproteinases (MMPs) and tissue inhibitors of matrix metalloproteinases (TIMPs). As such, cardiac fibroblasts can impact molecular and cellular events that collectively determine cardiac structure and function. variety of bioactive molecules and secrete them into the myocardial interstitium. These molecules include cytokines (TNF $\alpha$, interleukins and TGF $\beta$ ), active peptides (angiotensin II, endothelin 1) and growth factors [61], which function in the myocardium in autocrine and/or paracrine fashions. CFBs are the key cell type responsible for ECM homeostasis in health and its remodeling in heart disease. CFBs synthesize the ECM proteins while also producing the enzymes that degrade these proteins, and inhibitors of these enzymes. In this review, we will focus on the function of CFBs in the context of ECM formation, homeostasis and remodeling in different types of heart disease.

\section{Cardiac fibroblasts are critical in extracellular matrix homeostasis}

One of the primary functions of CFBs is maintaining the integrity of the cardiac ECM, a network structure that in addition to providing structural and functional integrity to the heart, also contains a number of cytokines and growth factors that can impact cardiac function and the fate of cardiac cells. Cardiac ECM is critical in mediating the mechanical connection among the cardiomyocytes, CFBs and the blood vessels within the myocardium. The ECM also transmits extracellular mechanical signals to the cardiomyocytes. The ECM is mainly comprised of fibrillar collagen types I and III, as well as less abundant collagen types IV, V and VI. The ECM also includes fibronectin, laminin, elastin and fibrillin, proteoglycans and glycoproteins. CFBs are the primary source of all of these ECM proteins [62], which can be induced by a number of growth factors such as platelet-derived growth factor, basic fibroblast growth factor and TGF $\beta$ during development and disease [63].

In addition to producing ECM proteins, CFBs also produce ECM-regulatory proteins - matrix metalloproteinases (MMPs), which can degrade ECM proteins and their inhibitors, tissue inhibitors of metalloproteinases (TIMPs). A well-controlled balance between the function of MMPs and TIMPs is critical in maintaining ECM homeostasis [64]. MMPs are the predominant proteases responsible for degradation of the ECM proteins. MMPs are $\mathrm{Zn}^{2+}$-activated proteases that are synthesized as inactive zymogens (pro-MMPs), and can be activated by removal of an amino-terminal propeptide domain and exposure of the catalytic domain. Among the 26 MMPs cloned and characterized in vertebrates, the MMPs so far identified to be involved in myocardial remodeling are as follows: MMP1, MMP3, MMP8, MMP13, MMP2, MMP9, MMP12, MMP28 and the membrane-type MMPs (MT1-MMP/MMP14) [65-69], although the role of higher MMPs in the cardiovascular system is less well explored. MMP1 degrades collagen types I, II and III and the basement membrane proteins, 
MMP12 targets elastin, MMP8 and MMP13 can process collagen types I, II and III, while MT1-MMP can cleave a number of ECM proteins including fibronectin, laminin-1 and fibrillar collagen type I [70-73]. Although classically known as gelatinases, MMP2 and MMP9 also process a number of collagens, including collagen types I, IV and V, while MMP2 additionally cleaves collagen type III [74]. Rodents lack the MMP1 gene but express MMP1a (mColA) and MMP1b (mColB) genes [75], primarily in the reproductive organs but not in the heart [76]. The proteolytic activity of MMPs is kept in check by TIMPs, the predominant inhibitors of MMPs in the myocardium [64]. Four TIMPs have so far been cloned [77], among which TIMP2, TIMP3 and TIMP4 are expressed in the healthy heart, whereas TIMP1 is expressed at low levels in the healthy heart but its levels rise in diseased hearts [76,78-80]. TIMPs can inhibit several MMPs, while they each also possess unique properties [81]. Although MMPs and TIMPs are best known for their functions in ECM homeostasis, they also possess a number of other functions and properties that have been discussed elsewhere $[64,82]$.

CFBs can produce a number of MMPs and TIMPs [83-86] whereby they can impact different aspects of ECM homeostasis and remodeling. A number of growth factors, cytokines, and chemokines have been identified that can regulate production of MMPs and TIMPs by CFBs. Proinflammatory cytokines such as TNF $\alpha$ and IL$1 \beta$ induce transcription of a number of MMPs, TIMP1 and TIMP2 in the myocardium [87]. Brain natriuretic peptide (BNP) has been reported to be produced by CFBs and to induce production of MMP1, MMP2, MMP3, MMP14 and TIMP2 [88]. Adult mouse FBs have been reported to synthesize a number of soluble secreted MMPs (MMP13, MMP8, MMP2, and MMP9), and two MT-MMPs (MMP14 (MT1-MMP) and MMP16 (MT3MMP)) [83]. Using a range of MMP-deficient mice $\left(\mathrm{MMP}^{-13^{-/}}, \mathrm{MMP}^{-/-}, \mathrm{MMP2}^{-/-}, \mathrm{MMP9}^{-/-}, \mathrm{MMP}^{-14^{-/-}}\right.$ (or MT1-MMP ${ }^{-1-}$ ) and $\mathrm{MMP}^{-/-}$(or MT3-MMP ${ }^{-/-}$)), Sabeh and colleagues demonstrated that only the membrane-anchored MMP14 is required for focal collagen invasion required for FB migration through the stroma, compared with bulk collagenolysis by the soluble MMPs [89].

While CFBs are the main source of ECM regulatory proteins, MMPs and TIMPs, these molecules can also impact on CFB function. MT1-MMP can cleave a number of ECM proteins including fibronectin, laminin-1 and fibrillar collagen type I [70-73], and has been shown to also trigger fibrosis by cleaving and activating the latent ECM-bound TGF $\beta$, activating the Smad pathway in CFBs and triggering collagen production [90,91]. MMP2 and MMP9 have been shown to release the ECM-bound latent TGF $\beta$, thereby inducing collagen synthesis [92].
Consistently, cardiac overexpression of MMP2 led to severe myocardial fibrosis [93]. In quiescently cultured human CFBs, overexpression of TIMPs using specific adenoviruses showed that each TIMP can impact the function of CFB differently [94]. Overexpression of Ad-TIMP1, Ad-TIMP2, Ad-TIMP3 and Ad-TIMP4 increased $\alpha \mathrm{SMA}$ levels, indicating differentiation of CFBs into myoFBs. Ad-TIMP2 increased collagen synthesis by CFBs, whereas Ad-TIMP3 increased FB apoptosis. These functions of TIMPs were independent from their MMP-inhibitory function [94]. These findings collectively indicate that while CFBs produce ECM proteins and the ECM-regulatory proteins, they are in turn influenced by these factors working as a self-regulating cycle.

\section{Remodeling of myocardial extracellular matrix in heart disease patients}

Remodeling of the ECM is a key component of cardiac remodeling that occurs in disease. Disruption of the ECM network structure interrupts the connection between the myocardial cells and blood vessels, thereby compromising the structural integrity and function of the heart. On the other hand, excess production and accumulation of ECM structural proteins, or fibrosis, results in enhanced stiffness of the myocardium and impedes ventricular contraction and relaxation, leading to distorted architecture and function of the heart. Excess collagen deposition and fibrosis has been clearly linked to myocardial stiffness, diastolic and systolic dysfunction [95]. Fibrosis can be the result of hyperactivity of existing FBs that proliferate rapidly in response to injury, or recruitment and proliferation of circulating bone-marrow-derived cells that can enter the myocardium and transform into FBs and myoFBs.

Fibrillar collagen types I and III are the predominant components of cardiac ECM. These collagens are produced as pro-collagens that are then processed into mature collagen molecules upon cleavage of their propeptide domain by procollagen peptidase. Assembly and cross-linking of mature collagen molecules gives rise to collagen fibrils and collagen fibers. During physiological ECM turnover or pathological ECM remodeling, collagen fibers are degraded and the telopeptides in the amino-terminals or carboxy-terminals of collagen molecules are cleaved (Figure 3). The pro-peptide from the carboxy-terminal or the amino-terminal propeptides of collagen type I (PICP, PINP), and those of collagen type III (PIIICP, PIIINP) are released during biosynthesis of these collagens in a stoichiometric manner, and hence are considered biomarkers of collagen synthesis. However, the carboxy-terminal or amino-terminal telopeptide of collagen type I (CITP, NITP) and type III (CIIITP, NIIITP), which are produced when these collagens are degraded, are considered biomarkers of collagen 


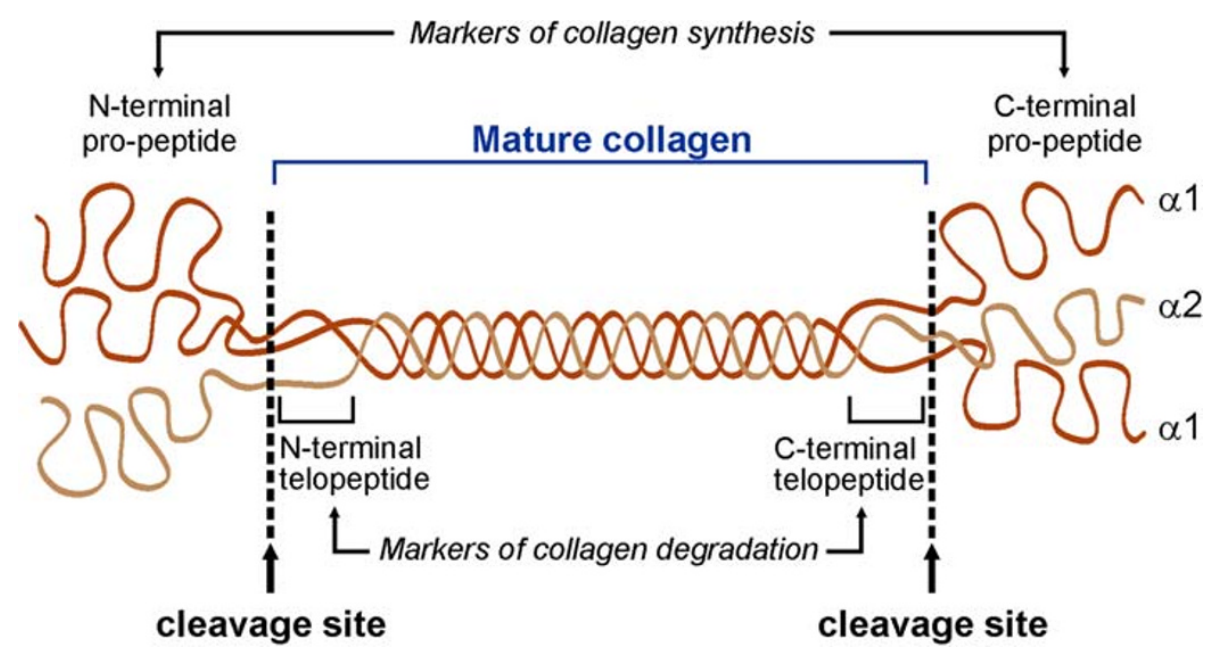

Figure 3 Structure of collagen molecule. Pro-collagen is comprised of two alpha- 1 chains and one alpha-2 chain intertwined into a triple helix. Pro-peptide domains at the carboxy-terminals and amino-terminals are cleaved, resulting in formation of mature collagen. When collagen is degraded, during physiological turnover or pathological adverse remodeling, telopeptides (from the amino-terminals or carboxy-terminals) are cleaved and released into the plasma.

degradation [96]. Measurement of these biomarkers in heart disease patients has provided insight into cardiac ECM remodeling in different types of heart disease.

Different reports have been made with respect to collagen turnover in hypertensive patients. Reduced serum CITP, a marker of collagen type I degradation, was suggested to explain collagen deposition and fibrosis in hypertensive patients [97], whereas a later study showed increased CITP as well as PICP (a marker of collagen synthesis) in hypertensive patients with left ventricular (LV) fibrosis and diastolic dysfunction indicating increased overall collagen turnover in these patients [98]. Using endomyocardial biopsies from hypertensive patients, a direct correlation was found between serum PICP and collagen volume fraction, while PICP levels were also higher in patients with severe fibrosis compared with those with less severe fibrosis [99]. Similarly, serum levels of PINP correlated with diastolic dysfunction in hypertensive patients without diabetes [100], suggesting that a serum marker of collagen synthesis (PICP or PINP) could be used as a biomarker for fibrosis in hypertensive patients. In hypertrophic cardiomyopathy, ECM turnover is a major determinant of cardiac remodeling. In patients with congestive heart failure, high serum levels of cardiac fibrosis (PIIINP and PICP) are significantly associated with poor outcome [101].

In patients with coronary artery disease but no MI, serum levels of PIIINP, but not PINP, correlated well with the number of diseased vessels and severity of coronary artery disease [102]. In addition, in patients with acute myocardial infarction (AMI), elevated serum PIIINP levels during the first few days post MI was associated with suppressed LV function, increased LV volume over 1-year follow-up [103], poor overall prognosis and survival [104]. Early post-MI serum PIIINP levels have been suggested to serve as a marker of long-term LV remodeling and prognosis. However, a more recent study reported that CITP served as the most suitable prognostic tool in patients with acute and chronic MI compared with PINP, PIIINP and TIMP1 [105].

In using plasma biomarkers for ECM remodeling in patients with heart disease, it is important to keep in mind that collagen type I is the most abundant collagen in the human body and is ubiquitously expressed in almost all organs and tissues in the body. Although collagen type III shows a relatively more tissue-specific expression pattern, it is also highly expressed in the skin, lungs and the vasculature. Hence, development of more cardiac-specific plasma biomarkers would provide more accurate insight into ECM alterations in the myocardium.

\section{Alterations in MMPs and TIMPs in heart disease patients}

Alterations in MMPs and TIMPs levels have been studied in different types of heart disease as a surrogate measure of myocardial ECM remodeling. In patients with end-stage dilated cardiomyopathy, analysis of LV myocardial tissue showed decreased MMP1, increased MMP3, MMP9, TIMP1 and TIMP2, and no changes in MMP2 levels [106]. Picard and colleagues reported increased MMP1 and TIMP1 mRNA levels in right septal endomyocardial biopsies from patients with dilated cardiomyopathy that did not correlate with LV diameter, whereas collagen volume density correlated well with LV diameter in these patients [107]. Hypertensive patients with cardiac hypertrophy have been reported to have 
reduced plasma levels of MMP1 [97], MMP2 and MMP9 [108], while elevated plasma TIMP1 levels have been reported in hypertensive patients [97] that correlated with diastolic dysfunction and LV fibrosis [98].

In patients with $\mathrm{MI}$ and unstable angina, serum levels of MMP2 and MMP9 (but not MMP1), TIMP1, TNF $\alpha$ and IL-6 were significantly elevated compared with healthy controls, suggesting that these MMPs, TIMP1 and proinflammatory cytokines could play an important role in the pathophysiology of acute coronary syndrome [109]. Measurement of temporal changes in plasma MMPs and TIMPs levels following MI showed a rapid and sustained increase in MMP9 and MMP8, with a delayed increase in TIMP2 and TIMP4 levels [110]. Plasma levels of MMP2 and MMP9 were elevated in AMI patients, but only the MMP9 levels exhibited a biphasic profile that peaked within the first 12 hours and then fell to a plateau [110]. This report is consistent with an earlier study that reported the early peak in MMP9 levels correlated with white blood cell and neutrophil counts after AMI, and inversely correlated with LV ejection fraction and LV end-diastolic volume during the follow-up, whereas the higher plateau levels later after AMI were associated with better LV function and LV remodeling [111]. However, plasma MMP9 has also been reported to serve as a useful prognostic tool in patients with AMI, where during the 2-year follow-up plasma MMP9 levels (but not MMP2, TNF $\alpha$, C-reactive protein, creatine kinase or pro-BNP) were the only predictive of late-onset congestive heart failure [112]. Overall, plasma biomarkers and their levels can be influenced by the type, severity and stage of disease, which should be taken into consideration when comparing reports from different studies.

\section{Experimental models of heart disease and extracellular matrix remodeling}

MI results from occlusion of a coronary artery, subjecting the downstream myocardial tissue to hypoxia and ischemia. The remodeling process consists of a series of timed molecular events that include recruitment of inflammatory cells, proliferation of CFBs or recruitment of circulating bone-marrow-derived cells and their differentiation to myoFBs, and formation of the fibrotic scar tissue. Experimental models of myocardial ischemic injury can be generated in different species by permanent or temporary ligation of the left anterior descending coronary artery resulting in MI or ischemia-reperfusion, respectively. Ischemia-reperfusion results in greater inflammatory cell influx and prolonged inflammatory response compared with MI, whereas in the MI model a greater number of CFBs are detected at the injury site, which correlates well with greater degree of fibrosis and ECM remodeling in the MI compared with the ischemia-reperfusion model [113]. CFBs are a critical element of myocardial repair that produce collagens, providing the tensile strength for cardiac tissue [1]. As such, interruption or hindrance of CFB activation will lead to decreased tensile strength of the cardiac wall, predisposing the cardiac chambers to dilate from the pressure of the blood within the chamber. Although inhibition of fibrosis post MI in mice lacking secreted frizzled-related proteins-2 was reported to result in beneficial outcomes [114], a recent study showed that inhibiting CFBs (by interrupting the wnt $/ \beta$-catenin signaling) prevented fibrosis, impaired the wound healing, and accelerated cardiac dilation and dysfunction within a few days of myocardial ischemic injury in mice [115]. This study clearly indicates that the post-MI fibrosis is reparative, and in fact a healing process and interruption of this process may bear unfavorable outcomes [116]. The wnt- $1 / \beta$-catenin has also been identified as a key pro-fibrotic signaling pathway in myocardial ischemiareperfusion injury, activating the epicardial cells to undergo epithelial-to-mesenchymal transformation, generating FBs, triggering CFB proliferation and expression of profibrotic genes [116]. Following myocardial ischemic injury, MMPs mediate a number of cellular responses, such as inflammation and fibrosis, through processing the ECM proteins as well as non-ECM substrates. MMP-mediated degradation of the ECM generates fragments that serve as chemoattractants triggering infiltration of inflammatory cells to the site of injury. The infiltrating macrophages and neutrophils in turn produce a number of MMPs, such as MMP8, MMP9 and MMP12 [117-120], which then further contribute to the adverse remodeling.

In hypertensive heart disease, reactive myocardial fibrosis increases myocardial stiffness and reduces compliance. Roles of MMPs and TIMPs have been indicated in the myocardial fibrosis in a number of hypertensive animal models. Deoxycorticosterone acetate salthypertensive rats showed higher collagen deposition through endothelin-1-mediated TGF $\beta$ expression [121]. This was later reported to be preceded by increased fibronectin expression, which could contribute to ECM cell attachment and promote collagen deposition, as well as elevated gelatinase levels (MMP2 and MMP9) [122].

While TGF $\beta$ is well known to activate the Smad signaling pathway in CFBs, thereby mediating FB activation and collagen production, a recent study by Koitabashi and colleagues demonstrated that the TGF $\beta$ signaling pathway in the cardiomyocytes via TGF $\beta$-receptor 2 plays a critical role in myocardial fibrosis following pressure overload [123]. Cardiomyocyte-specific knockdown of TGF $\beta$-receptor 2 completely blocked myocardial fibrosis and LV dysfunction, activation of the Smad pathway as well as TGF $\beta$-activated kinase 1 and preserved 
capillary density. However, cardiomyocyte knockdown of TGF $\beta$-receptor 1 or treatment with a TGF $\beta$ neutralizing antibody only suppressed the Smad activity (not TGF $\beta$ activated kinase 1) and partially suppressed fibrosis without improving LV function [123]. As such, TGF $\beta$ mediated activation of TGF $\beta$-activated kinase 1in cardiomyocytes was proposed to underlie the maladaptive hypertrophy and dysfunction secondary to cardiac pressure overload.

Atrial natriuretic peptide and BNP have been shown to inhibit FB proliferation, collagen synthesis and MMP release via activation of the cGMP pathway [124], and to oppose the TGF $\beta$-induced ECM protein synthesis in vitro $[125,126]$. These findings are particularly interesting since FBs are also an important source of natriuretic peptides, and as such can generate a negative feedback loop [127]. Deletion of the major natriuretic receptor for atrial natriuretic peptide and BNP, natriuretic peptide receptor- 1 in mice $\left(\mathrm{Npr}^{-/-}\right)$, resulted in hypertension, cardiac hypertrophy, congestive heart failure and sudden death at 6 months of age $[128,129]$. Elevated levels of MMP2, MMP9 and TNFa in these mice were linked to increased production of collagen types I and III by CFBs in a TGF $\beta$-dependent manner, leading to myocardial fibrosis [130]. Atrial natriuretic peptide and BNP levels are consistently elevated in heart disease in patients [131,132] as well as in experimental models of heart disease $[133,134]$, and are consistently linked to severity and progression of disease [135]. Taken together, these elevated atrial natriuretic peptide and BNP levels in heart disease could be a protective attempt by the myocardial tissue to limit excess fibrotic deposition, tissue injury and adverse remodeling.

\section{MMPs, TIMPs, myocardial remodeling and fibrosis}

As discussed earlier, a tightly controlled balance between the function of MMPs and TIMPs is critical in maintaining the ECM integrity. A number of experimental animal models have been developed in order to determine the contribution of MMPs and TIMPs in ECM remodeling in heart disease, and genetically modified mice have provided valuable tools in examining the causal role of MMPs and TIMPs in this process.

\section{Remodeling following myocardial infarction}

Targeted deletion of MMP2 improved post-MI survival by hindering macrophage infiltration and reducing the rate of LV rupture [136]. MMP7 has been shown to cleave the gap junction connexin-43, thereby promoting an arrythmogenic response post MI. MMP7 deletion therefore improved post-MI survival and improved myocardial conduction pattern owing to preserved connexin-43 levels [137]. MMP9 deletion provided partial protection against post-MI rupture [138], while reducing LV dilation and dysfunction [139]. Lack of individual TIMPs influenced different aspects of cardiac structure and function following MI. In TIMP1 ${ }^{-/-}$mice, MI led to greater LV dilation and increased LV enddiastolic volume compared with parallel wildtype mice [140]. In mice lacking TIMP2, MI exacerbated LV dilation and reduced the ejection fraction but did not alter the rate of LV rupture compared with WT-MI mice [78]. Lack of TIMP3 increased the rate of LV rupture, worsened LV dilation and reduced ejection fraction following MI [133], whereas TIMP4 deficiency only increased the rate of LV rupture without affecting the LV structure or function post MI [141]. While lack of TIMP2 and TIMP3 exacerbated infarct expansion, the increased rate of LV rupture in $\mathrm{TIMP}^{-/-}$and $\mathrm{TIMP}^{-/-}$impaired ECM remodeling in these mice. Second harmonic generation imaging further revealed reduced density and greater disarray of fibrillar collagens in the infarct myocardium of TIMP3 $^{-/-}$and TIMP4 ${ }^{-1-}$, consistent with the increased rate of LV rupture in these mice [133,141]. These data indicate that while TIMP1, TIMP2 and TIMP3 exert a global impact altering the overall structure and function of the LV myocardium, the function of TIMP4 appears to be localized to the infarcted myocardium.

Mice overexpressing MT1-MMP showed lower survival and ejection fraction post MI compared with parallel wildtype mice, whereas these parameters were improved in mice with reduced MT1-MMP levels $\left(\mathrm{MT}^{-\mathrm{MMP}^{+/-}}\right.$) [90]. Overexpression of TIMP1 has been shown to have beneficial effects in mouse [142] and rat [143] models of MI. Additionally, overexpression of TIMP2 in the peri-infarct myocardium reduced the infarct expansion and improved LV dilation and dysfunction [144].

\section{Fibrosis and ECM remodeling in hypertension and cardiac pressure overload}

Pressure overload exerts a mechanical stress on the ventricles and can trigger cardiac hypertrophy and fibrosis. In this model of heart disease, the excessive biomechanical stress is transmitted to ECM and cell-ECM connections that can lead to adverse remodeling of the ECM, and can further activate the intracellular signaling pathways leading to cardiac hypertrophy, fibrosis and cell death. MMP2-deficient mice showed reduced myocardial hypertrophy and fibrosis [145], while MMP9 deficiency partially improved myocardial hypertrophy and fibrosis following pressure overload [146]. We recently reported that in response to cardiac pressure overload, TIMP2 $2^{-1-}$ mice exhibit greater LV dilation and dysfunction, with non-homogeneous ECM remodeling which was characterized by areas of disrupted ECM network adjacent to regions of fibrotic lesions [134]. Myocardial fibrosis in 
pressure-overloaded $\mathrm{TIMP}^{-/-}$hearts was not due to increased expression of collagen type I and/or type III, however, but due to elevated levels of SPARC (secreted protein acidic and rich in cysteine) and enhanced posttranslational stabilization of collagen fibers [134]. Cardiac pressure overload in TIMP3-deficient mice led to exacerbated LV remodeling, and dysfunction [147], and to severe myocardial fibrosis [148]. The exacerbated LV dilation and dysfunction in these mice was found to be due to the combined contribution of augmented MMPmediated proteolytic activities and heightened the TNF $\alpha$-converting enzyme-TNF $\alpha$ pathway [147], while myocardial fibrosis was found to be mediated through an interaction between the TNF $\alpha$ and TGF $\beta$ pathways that led to increased expression of fibrillar collagens [148]. Interestingly, TIMP4 was found not to contribute to cardiac response to mechanical stress, as TIMP4 $4^{-1-}$ mice exhibited comparable cardiac remodeling, dysfunction and myocardial fibrosis compared with the parallel wildtype mice [141].

\section{Conclusion}

The ECM is an integral component of the myocardium, and the factors that influence the integrity of the ECM structure also impact cardiac structure and function. Cardiac FBs play a central role in the physiological turnover of the ECM as well as its pathological remodeling. Although cardiac FBs are often associated with cardiac fibrosis and adverse outcomes, it is important to note that the primary function of FBs is tissue repair (wound healing) - which in cases such as MI is in fact beneficial, and its interruption would have undesirable outcomes. In addition, MMPs are traditionally known for degrading the ECM proteins, and TIMPs to inhibit this process. However, MMPs can also promote ECM production (and fibrosis) by regulating the activity of FBs, and similarly TIMPs can influence FB behavior and ECM production in a MMP-independent fashion. Hence, it is critical to understand the diverse functions of MMPs, TIMPs and FBs towards developing effective therapies to control harmful myocardial fibrosis.

\footnotetext{
Abbreviations

AMI: acute myocardial infarction; aSMA: alpha smooth muscle actin; BNP: brain natriuretic peptide; CFB: cardiac fibroblast; CITP: carboxy-terminal telopeptide of collagen type I; CIIITP: carboxy-terminal telopeptide of collagen type III; DDR: discoidin domain receptor; ECM: extracellular matrix; FB: fibroblast; IL: interleukin; LV: left ventricular; MI: myocardial infarction; miRNA: microRNA; MMP: matrix metalloproteinase; MT-MMP: membrane-type matrix metalloproteinase; myoFB: myofibroblast; NITP: amino-terminal telopeptide of collagen type I; NIIITP: amino-terminal telopeptide of collagen type III; PICP: carboxy-terminal propeptides of collagen type I (or procollagen type I carboxy-terminal propeptide); PINP: amino-terminal propeptides of collagen type I (or procollagen type I amino-terminal propeptide); PIIICP: carboxy-terminal propeptides of collagen type III (or procollagen type III carboxy-terminal propeptide); PIIINP: amino-terminal propeptides of collagen type III (or Procollagen type III amino-terminal propeptide);
}

TIMP: tissue inhibitor of metalloproteinase; TGF $\beta$ : transforming growth factor beta; TNF: tumor necrosis factor.

\section{Competing interests}

The authors declare that they have no competing interests.

\section{Authors' contributions}

DF and ZK conceived the original concept of the review. DF contributed to $50 \%$, and AT and $J \mathrm{~L}$ each contributed to $25 \%$ of the first draft. All authors read and approved the final manuscript.

\section{Acknowledgements}

ZK is a New Investigator of the Heart and Stroke Foundation of Canada and the Alberta Innovates-Health Solution Scholar. This work was supported by a Canadian Institute of Health Research grant (CIHR 84279) and a Heart and Stroke Foundation of Canada research grant to ZK.

Received: 2 July 2012 Accepted: 16 August 2012

Published: 3 September 2012

\section{References}

1. Camelliti P, Borg TK, Kohl P: Structural and functional characterisation of cardiac fibroblasts. Cardiovasc Res 2005, 65:40-51.

2. Souders CA, Bowers SL, Baudino TA: Cardiac fibroblast: the renaissance cell. Circ Res 2009, 105:1164-1176.

3. Hill JA, Olson EN: Cardiac plasticity. N Engl J Med 2008, 358:1370-1380.

4. Koitabashi N, Kass DA: Reverse remodeling in heart failure - mechanisms and therapeutic opportunities. Nat Rev Cardiol 2012, 9:147-157.

5. Kranias EG, Hajjar RJ: Modulation of cardiac contractility by the phopholamban/SERCA2a regulatome. Circ Res 2012, 110:1646-1660.

6. Krenning G, Zeisberg EM, Kalluri R: The origin of fibroblasts and mechanism of cardiac fibrosis. J Cell Physiol 2010, 225:631-637.

7. Fries KM, Blieden T, Looney RJ, Sempowski GD, Silvera MR, Willis RA, Phipps RP: Evidence of fibroblast heterogeneity and the role of fibroblast subpopulations in fibrosis. Clin Immunol Immunopathol 1994, 72:283-292.

8. Franke WW, Schmid E, Osborn M, Weber K: Intermediate-sized filaments of human endothelial cells. J Cell Biol 1979, 81:570-580.

9. Mork C, van Deurs B, Petersen OW: Regulation of vimentin expression in cultured human mammary epithelial cells. Differentiation 1990, 43:146-156.

10. Camelliti P, Green CR, LeGrice I, Kohl P: Fibroblast network in rabbit sinoatrial node: structural and functional identification of homogeneous and heterogeneous cell coupling. Circ Res 2004, 94:828-835.

11. Goldsmith EC, Hoffman A, Morales MO, Potts JD, Price RL, McFadden A, Rice M, Borg TK: Organization of fibroblasts in the heart. Dev Dyn 2004, 230:787-794.

12. Shrivastava A, Radziejewski C, Campbell E, Kovac L, McGlynn M, Ryan TE, Davis S, Goldfarb MP, Glass DJ, Lemke G, Yancopoulos GD: An orphan receptor tyrosine kinase family whose members serve as nonintegrin collagen receptors. Mol Cell 1997, 1:25-34.

13. Vogel W, Gish GD, Alves F, Pawson T: The discoidin domain receptor tyrosine kinases are activated by collagen. Mol Cell 1997, 1:13-23.

14. Schlessinger J: Direct binding and activation of receptor tyrosine kinases by collagen. Cell 1997, 91:869-872.

15. Alves F, Vogel W, Mossie K, Millauer B, Hofler H, Ullrich A: Distinct structural characteristics of discoidin I subfamily receptor tyrosine kinases and complementary expression in human cancer. Oncogene 1995, 10:609-618.

16. Lai C, Lemke G: An extended family of protein-tyrosine kinase genes differentially expressed in the vertebrate nervous system. Neuron 1991, 6:691-704.

17. Ebihara $Y$, Masuya M, Larue AC, Fleming PA, Visconti RP, Minamiguchi H, Drake CJ, Ogawa M: Hematopoietic origins of fibroblasts: II. In vitro studies of fibroblasts, CFU-F, and fibrocytes. Exp Hematol 2006, 34:219-229.

18. Shyu KG, Chao YM, Wang BW, Kuan P: Regulation of discoidin domain receptor 2 by cyclic mechanical stretch in cultured rat vascular smooth muscle cells. Hypertension 2005, 46:614-621.

19. Ferri N, Carragher NO, Raines EW: Role of discoidin domain receptors 1 and 2 in human smooth muscle cell-mediated collagen remodeling: potential implications in atherosclerosis and lymphangioleiomyomatosis. Am J Pathol 2004, 164:1575-1585. 
20. Mohan RR, Wilson SE: Discoidin domain receptor (DDR) 1 and 2: collagenactivated tyrosine kinase receptors in the cornea. Exp Eye Res 2001, 72:87-92.

21. Strutz F, Okada H, Lo CW, Danoff T, Carone RL, Tomaszewski JE, Neilson EG: Identification and characterization of a fibroblast marker: FSP1. J Cell Biol 1995, 130:393-405.

22. Mazzucchelli L: Protein S100A4: too long overlooked by pathologists? Am J Pathol 2002, 160:7-13.

23. Petrov W, Fagard RH, Lijnen PJ: Stimulation of collagen production by transforming growth factor-beta1 during differentiation of cardiac fibroblasts to myofibroblasts. Hypertension 2002, 39:258-263.

24. Gabbiani G, Ryan GB, Majne G: Presence of modified fibroblasts in granulation tissue and their possible role in wound contraction. Experientia 1971, 27:549-550.

25. Baum J, Duffy HS: Fibroblasts and myofibroblasts: what are we talking about? J Cardiovasc Pharmacol 2011, 57:376-379.

26. Tomasek JJ, Gabbiani G, Hinz B, Chaponnier C, Brown RA: Myofibroblasts and mechano-regulation of connective tissue remodelling. Nat Rev Mol Cell Biol 2002, 3:349-363.

27. Santiago JJ, Dangerfield AL, Rattan SG, Bathe KL, Cunnington RH, Raizman JE, Bedosky KM, Freed DH, Kardami E, Dixon IM: Cardiac fibroblast to myofibroblast differentiation in vivo and in vitro: expression of focal adhesion components in neonatal and adult rat ventricular myofibroblasts. Dev Dyn 2010, 239:1573-1584.

28. Gabbiani G: The myofibroblast in wound healing and fibrocontractive diseases. J Pathol 2003, 200:500-503.

29. Calderone A, Bel-Hadj S, Drapeau J, El-Helou V, Gosselin H, Clement R, Villeneuve $L$ : Scar myofibroblasts of the infarcted rat heart express natriuretic peptides. J Cell Physiol 2006, 207:165-173.

30. Tamaoki M, Imanaka-Yoshida K, Yokoyama K, Nishioka T, Inada H, Hiroe M, Sakakura T, Yoshida T: Tenascin-C regulates recruitment of myofibroblasts during tissue repair after myocardial injury. Am J Pathol 2005, 167:71-80.

31. Walker GA, Masters KS, Shah DN, Anseth KS, Leinwand LA: Valvular myofibroblast activation by transforming growth factor-beta: implications for pathological extracellular matrix remodeling in heart valve disease. Circ Res 2004, 95:253-260.

32. Lie-Venema H, van den Akker NM, Bax NA, Winter EM, Maas S, Kekarainen T, Hoeben RC, de Ruiter MC, Poelmann RE, Gittenberger-de Groot AC: Origin, fate, and function of epicardium-derived cells (EPDCs) in normal and abnormal cardiac development. ScientificWorldJournal 2007, 7:1777-1798.

33. Norris RA, Borg TK, Butcher JT, Baudino TA, Banerjee I, Markwald RR: Neonatal and adult cardiovascular pathophysiological remodeling and repair: developmental role of periostin. Ann N Y Acad Sci 2008, 1123:30-40

34. Olivey HE, Mundell NA, Austin AF, Barnett JV: Transforming growth factorbeta stimulates epithelial-mesenchymal transformation in the proepicardium. Dev Dyn 2006, 235:50-59.

35. Gittenberger-de Groot AC, Vrancken Peeters MP, Mentink MM, Gourdie RG, Poelmann RE: Epicardium-derived cells contribute a novel population to the myocardial wall and the atrioventricular cushions. Circ Res 1998, 82:1043-1052

36. Kolditz DP, Wijffels MC, Blom NA, van der Laarse A, Hahurij ND, Lie-Venema H, Markwald RR, Poelmann RE, Schalij MJ, Gittenberger-de Groot AC: Epicardium-derived cells in development of annulus fibrosis and persistence of accessory pathways. Circulation 2008, 117:1508-1517.

37. Zhou B, von Gise A, Ma Q, Hu YW, Pu WT: Genetic fate mapping demonstrates contribution of epicardium-derived cells to the annulus fibrosis of the mammalian heart. Dev Biol 2010, 338:251-261.

38. de Lange FJ, Moorman AF, Anderson RH, Manner J, Soufan AT, de Gier-de Vries C, Schneider MD, Webb S, van den Hoff MJ, Christoffels VM: Lineage and morphogenetic analysis of the cardiac valves. Circ Res 2004, 95:645-654.

39. Lucas JA, Zhang Y, Li P, Gong K, Miller AP, Hassan E, Hage F, Xing D, Wells B, Oparil S, Chen YF: Inhibition of transforming growth factor-beta signaling induces left ventricular dilation and dysfunction in the pressure-overloaded heart. Am J Physiol Heart Circ Physiol 2010, 298:H424-H432.

40. Zeisberg EM, Tarnavski O, Zeisberg M, Dorfman AL, McMullen JR, Gustafsson E, Chandraker A, Yuan X, Pu WT, Roberts AB, Neilson EG, Sayegh MH, Isumo $S$, Kalluri R: Endothelial-to-mesenchymal transition contributes to cardiac fibrosis. Nat Med 2007, 13:952-961.
41. Wynn TA, Ramalingam TR: Mechanisms of fibrosis: therapeutic translation for fibrotic disease. Nat Med 2012, 18:1028-1040.

42. Garcia J, Sandi MJ, Cordelier P, Binetruy B, Pouyssegur J, lovanna JL, Tournaire R: Tie1 deficiency induces endothelial-mesenchymal transition. EMBO Rep 2012, 13:431-439.

43. Russell JL, Goetsch SC, Gaiano NR, Hill JA, Olson EN, Schneider JW: A dynamic notch injury response activates epicardium and contributes to fibrosis repair. Circ Res 2011, 108:51-59.

44. Haudek SB, Xia Y, Huebener P, Lee JM, Carlson S, Crawford JR, Pilling D, Gomer RH, Trial J, Frangogiannis NG, Entman ML: Bone marrow-derived fibroblast precursors mediate ischemic cardiomyopathy in mice. Proc Natl Acad Sci U S A 2006, 103:18284-18289.

45. van Amerongen MJ, Bou-Gharios G, Popa E, van Ark J, Petersen AH, van Dam GM, van Luyn MJ, Harmsen MC: Bone marrow-derived myofibroblasts contribute functionally to scar formation after myocardial infarction. J Pathol 2008, 214:377-386.

46. van Amerongen MJ, Harmsen MC, van Rooijen $\mathrm{N}$, Petersen $\mathrm{AH}$, van Luyn MJ: Macrophage depletion impairs wound healing and increases left ventricular remodeling after myocardial injury in mice. Am J Pathol 2007, 170:818-829.

47. Ogawa M, LaRue AC, Drake CJ: Hematopoietic origin of fibroblasts/ myofibroblasts: Its pathophysiologic implications. Blood 2006, 108:2893-2896

48. Mollmann H, Nef HM, Kostin S, von Kalle C, Pilz I, Weber M, Schaper J, Hamm CW, Elsasser A: Bone marrow-derived cells contribute to infarct remodelling. Cardiovasc Res 2006, 71:661-671.

49. Kania G, Blyszczuk P, Stein S, Valaperti A, Germano D, Dirnhofer S, Hunziker L, Matter CM, Eriksson U: Heart-infiltrating prominin- $1^{+} / \mathrm{CD} 133^{+}$progenitor cells represent the cellular source of transforming growth factor betamediated cardiac fibrosis in experimental autoimmune myocarditis. Circ Res 2009, 105:462-470

50. Xu J, Lin SC, Chen J, Miao Y, Taffet GE, Entman ML, Wang Y: CCR2 mediates the uptake of bone marrow-derived fibroblast precursors in angiotensin II-induced cardiac fibrosis. Am J Physiol Heart Circ Physiol 2011, 301:H538-H547.

51. Humphreys BD, Lin SL, Kobayashi A, Hudson TE, Nowlin BT, Bonventre JV, Valerius MT, McMahon AP, Duffield JS: Fate tracing reveals the pericyte and not epithelial origin of myofibroblasts in kidney fibrosis. Am J Pathol 2010, 176:85-97.

52. Covas DT, Panepucci RA, Fontes AM, Silva WA Jr, Orellana MD, Freitas MC, Neder L, Santos AR, Peres LC, Jamur MC, Zago MA: Multipotent mesenchymal stromal cells obtained from diverse human tissues share functional properties and gene-expression profile with $\mathrm{CD} 146^{+}$ perivascular cells and fibroblasts. Exp Hematol 2008, 36:642-654.

53. Takahashi K, Yamanaka S: Induction of pluripotent stem cells from mouse embryonic and adult fibroblast cultures by defined factors. Cell 2006, 126:663-676.

54. Tapscott SJ, Davis RL, Thayer MJ, Cheng PF, Weintraub H, Lassar AB: MyoD1: a nuclear phosphoprotein requiring a Myc homology region to convert fibroblasts to myoblasts. Science 1988, 242:405-411.

55. Vierbuchen T, Ostermeier A, Pang ZP, Kokubu Y, Sudhof TC, Wernig M: Direct conversion of fibroblasts to functional neurons by defined factors. Nature 2010, 463:1035-1041.

56. Song K, Nam YJ, Luo X, Qi X, Tan W, Huang GN, Acharya A, Smith CL, Tallquist MD, Neilson EG, Hill JA, Bassel-Duby R, Olson EN: Heart repair by reprogramming non-myocytes with cardiac transcription factors. Nature 2012, 485:599-604

57. leda M, Fu JD, Delgado-Olguin P, Vedantham V, Hayashi Y, Bruneau BG, Srivastava D: Direct reprogramming of fibroblasts into functional cardiomyocytes by defined factors. Cell 2010, 142:375-386.

58. Jayawardena TM, Egemnazarov B, Finch EA, Zhang L, Payne JA, Pandya K, Zhang Z, Rosenberg P, Mirotsou M, Dzau VJ: MicroRNA-mediated in vitro and in vivo direct reprogramming of cardiac fibroblasts to cardiomyocytes. Circ Res 2012, 110:1465-1473.

59. Kohl P: Heterogeneous cell coupling in the heart: an electrophysiological role for fibroblasts. Circ Res 2003, 93:381-383.

60. Gaudesius G, Miragoli M, Thomas SP, Rohr S: Coupling of cardiac electrical activity over extended distances by fibroblasts of cardiac origin. Circ Res 2003, 93:421-428.

61. Porter KE, Turner NA: Cardiac fibroblasts: at the heart of myocardial remodeling. Pharmacol Ther 2009, 123:255-278. 
62. Eghbali M: Cardiac fibroblasts: function, regulation of gene expression and phenotypic modulation. Basic Res Cardiol 1992, 87(Suppl 2):183-189.

63. Butt RP, Laurent GJ, Bishop JE: Collagen production and replication by cardiac fibroblasts is enhanced in response to diverse classes of growth factors. Eur J Cell Biol 1995, 68:330-335.

64. Moore L, Fan D, Basu R, Kandalam V, Kassiri Z: Tissue inhibitor of metalloproteinases (TIMPs) in heart failure. Heart Fail Rev 2012, 17:693-706.

65. Spinale FG: Myocardial matrix remodeling and the matrix metalloproteinases: influence on cardiac form and function. Physiol Rev 2007, 87:1285-1342.

66. Mann DL, Spinale FG: Activation of matrix metalloproteinases in the failing human heart: breaking the tie that binds. Circulation 1998, 98:1699-1702

67. Spinale FG, Wilbur NM: Matrix metalloproteinase therapy in heart failure. Curr Treat Options Cardiovasc Med 2009, 11:339-346.

68. Kelly D, Khan S, Cockerill G, Ng LL, Thompson M, Samani NJ, Squire IB: Circulating stromelysin-1 (MMP-3): a novel predictor of LV dysfunction, remodelling and all-cause mortality after acute myocardial infarction. Eur $J$ Heart Fail 2008, 10:133-139.

69. Ma Y, Chiao YA, Zhang J, Manicone AM, Jin YF, Lindsey ML: Matrix metalloproteinase-28 deletion amplifies inflammatory and extracellular matrix responses to cardiac aging. Microsc Microanal 2012, 18:81-90.

70. Manso AM, Elsherif L, Kang SM, Ross RS: Integrins, membrane-type matrix metalloproteinases and ADAMs: potential implications for cardiac remodeling. Cardiovasc Res 2006, 69:574-584.

71. Barbolina MV, Stack MS: Membrane type 1-matrix metalloproteinase: substrate diversity in pericellular proteolysis. Semin Cell Dev Biol 2008, 19:24-33.

72. Takino T, Saeki H, Miyamori H, Kudo T, Sato H: Inhibition of membranetype 1 matrix metalloproteinase at cell-matrix adhesions. Cancer Res 2007, 67:11621-11629.

73. Shen XM, Wu YP, Feng YB, Luo ML, Du XL, Zhang Y, Cai $Y, X u X$, Han $Y L$, Zhang $X$, Zhan QM, Wang MR: Interaction of MT1-MMP and laminin-5Y2 chain correlates with metastasis and invasiveness in human esophageal squamous cell carcinoma. Clin Exp Metastasis 2007, 24:541-550.

74. Steffensen B, Wallon UM, Overall CM: Extracellular matrix binding properties of recombinant fibronectin type II-like modules of human 72 kDa gelatinase/type IV collagenase. High affinity binding to native type I collagen but not native type IV collagen. J Biol Chem 1995, 270:11555-11566.

75. Vincenti MP, Coon Cl, Mengshol JA, Yocum S, Mitchell P, Brinckerhoff CE: Cloning of the gene for interstitial collagenase-3 (matrix metalloproteinase-13) from rabbit synovial fibroblasts: differential expression with collagenase-1 (matrix metalloproteinase-1). Biochem $J$ 1998, 331(Pt 1):341-346.

76. Nuttall RK, Sampieri CL, Pennington CJ, Gill SE, Schultz GA, Edwards DR: Expression analysis of the entire MMP and TIMP gene families during mouse tissue development. FEBS Lett 2004, 563:129-134.

77. Visse R, Nagase H: Matrix metalloproteinases and tissue inhibitors of metalloproteinases: structure, function, and biochemistry. Circ Res 2003, 92:827-839

78. Kandalam V, Basu R, Abraham T, Wang X, Soloway PD, Jaworski DM, Oudit GY, Kassiri Z: TIMP2 deficiency accelerates adverse post-myocardial infarction remodeling because of enhanced MT1-MMP activity despite lack of MMP2 activation. Circ Res 2010, 106:796-808.

79. Li YY, Feng Y, McTiernan CF, Pei W, Moravec CS, Wang P, Rosenblum W, Kormos RL, Feldman AM: Downregulation of matrix metalloproteinases and reduction in collagen damage in the failing human heart after support with left ventricular assist devices. Circulation 2001, 104:1147-1152.

80. Heymans S, Schroen B, Vermeersch P, Milting H, Gao F, Kassner A, Gillijns H, Herijgers P, Flameng W, Carmeliet P, Van de Werf F, Pinto YM, Janssens S: Increased cardiac expression of tissue inhibitor of metalloproteinase-1 and tissue inhibitor of metalloproteinase- 2 is related to cardiac fibrosis and dysfunction in the chronic pressure-overloaded human heart. Circulation 2005, 112:1136-1144.

81. Moore L, Fan D, Basu R, Kandalam V, Kassiri Z: Tissue inhibitor of metalloproteinases (TIMPs) in heart failure. Heart Fail Rev 2012, 17:693-706.

82. Vanhoutte D, Heymans S: TIMPs and cardiac remodeling: 'Embracing the MMP-independent-side of the family'. J Mol Cell Cardiol 2010, 48:445-453.
83. Page-McCaw A, Ewald AJ, Werb Z: Matrix metalloproteinases and the regulation of tissue remodelling. Nat Rev Mol Cell Biol 2007, 8:221-233.

84. Shi Q, Liu X, Bai Y, Cui C, Li J, Li Y, Hu S, Wei Y: In vitro effects of pirfenidone on cardiac fibroblasts: proliferation, myofibroblast differentiation, migration and cytokine secretion. PLoS One 2011, 6:e28134.

85. Tyagi SC, Kumar SG, Banks J, Fortson W: Co-expression of tissue inhibitor and matrix metalloproteinase in myocardium. J Mol Cell Cardiol 1995, 27:2177-2189.

86. Awad AE, Kandalam V, Chakrabarti S, Wang X, Penninger JM, Davidge ST, Oudit GY, Kassiri Z: Tumor necrosis factor induces matrix metalloproteinases in cardiomyocytes and cardiofibroblasts differentially via superoxide production in a PI3KY-dependent manner. Am J Physiol Cell Physiol 2010, 298:C679-C692.

87. Deschamps AM, Spinale FG: Pathways of matrix metalloproteinase induction in heart failure: bioactive molecules and transcriptional regulation. Cardiovasc Res 2006, 69:666-676.

88. Tsuruda T, Boerrigter G, Huntley BK, Noser JA, Cataliotti A, CostelloBoerrigter LC, Chen HH, Burnett JC Jr: Brain natriuretic Peptide is produced in cardiac fibroblasts and induces matrix metalloproteinases. Circ Res 2002, 91:1127-1134.

89. Sabeh F, Li XY, Saunders TL, Rowe RG, Weiss SJ: Secreted versus membrane-anchored collagenases: relative roles in fibroblast-dependent collagenolysis and invasion. J Biol Chem 2009, 284:23001-23011.

90. Zavadzkas JA, Mukherjee R, Rivers WT, Patel RK, Meyer EC, Black LE, McKinney RA, Oelsen JM, Stroud RE, Spinale FG: Direct regulation of membrane type 1 matrix metalloproteinase following myocardial infarction causes changes in survival, cardiac function, and remodeling. Am J Physiol Heart Circ Physiol 2011, 301:H1656-H1666.

91. Spinale FG, Escobar GP, Mukherjee R, Zavadzkas JA, Saunders SM, Jeffords LB, Leone AM, Beck C, Bouges S, Stroud RE: Cardiac-restricted overexpression of membrane type-1 matrix metalloproteinase in mice: effects on myocardial remodeling with aging. Circ Heart Fail 2009, 2:351-360

92. Yu Q, Stamenkovic I: Cell surface-localized matrix metalloproteinase-9 proteolytically activates TGF-beta and promotes tumor invasion and angiogenesis. Genes Dev 2000, 14:163-176.

93. Bergman MR, Teerlink JR, Mahimkar R, Li L, Zhu BQ, Nguyen A, Dahi S, Karliner JS, Lovett DH: Cardiac matrix metalloproteinase-2 expression independently induces marked ventricular remodeling and systolic dysfunction. Am J Physiol Heart Circ Physiol 2007, 292:H1847-H1860.

94. Lovelock JD, Baker AH, Gao F, Dong JF, Bergeron AL, McPheat W, Sivasubramanian N, Mann DL: Heterogeneous effects of tissue inhibitors of matrix metalloproteinases on cardiac fibroblasts. Am J Physiol Heart Circ Physiol 2005, 288:H461-H468.

95. Diez J, Querejeta R, Lopez B, Gonzalez A, Larman M, Martinez Ubago JL: Losartan-dependent regression of myocardial fibrosis is associated with reduction of left ventricular chamber stiffness in hypertensive patients. Circulation 2002, 105:2512-2517.

96. Zannad F, Rossignol P, Iraqi W: Extracellular matrix fibrotic markers in heart failure. Heart Fail Rev 2010, 15:319-329.

97. Laviades C, Varo N, Fernandez J, Mayor G, Gil MJ, Monreal I, Diez J: Abnormalities of the extracellular degradation of collagen type I in essential hypertension. Circulation 1998, 98:535-540

98. Lindsay MM, Maxwell P, Dunn FG: TIMP-1: a marker of left ventricular diastolic dysfunction and fibrosis in hypertension. Hypertension 2002 40:136-141.

99. Querejeta R, Varo N, Lopez B, Larman M, Artinano E, Etayo JC, Martinez Ubago JL, Gutierrez-Stampa M, Emparanza Jl, Gil MJ, Monreal I, Mindan JP, Diez J: Serum carboxy-terminal propeptide of procollagen type I is a marker of myocardial fibrosis in hypertensive heart disease. Circulation 2000, 101:1729-1735.

100. Lin YH, Chiu YW, Shiau YC, Yen RF, Tsai IJ, Ho YL, Huang PJ: The relation between serum level of amioterminal propeptide of type I procollagen and diastolic dysfunction in hypertensive patients without diabetes mellitus: a pilot study. J Hum Hypertens 2006, 20:964-967.

101. Zannad F, Alla F, Dousset B, Perez A, Pitt B: Limitation of excessive extracellular matrix turnover may contribute to survival benefit of spironolactone therapy in patients with congestive heart failure: insights from the randomized aldactone evaluation study (RALES). Rales Investigators. Circulation 2000, 102:2700-2706. 
102. Lin $Y H$, Ho YL, Wang TD, Liu CP, Kao HL, Chao CL, Chien KL, Hung CS, Wu VC, Tsai IJ, Yen RF, Shiau YC, Chen WJ: The relation of amino-terminal propeptide of type III procollagen and severity of coronary artery disease in patients without myocardial infarction or hibernation. Clin Biochem 2006, 39:861-866.

103. Poulsen $\mathrm{SH}$, Host NB, Jensen SE, Egstrup K: Relationship between serum amino-terminal propeptide of type III procollagen and changes of left ventricular function after acute myocardial infarction. Circulation 2000, 101:1527-1532.

104. Host NB, Jensen LT, Bendixen PM, Jensen SE, Koldkjaer OG, Simonsen EE: The aminoterminal propeptide of type III procollagen provides new information on prognosis after acute myocardial infarction. Am J Cardiol 1995, 76:869-873.

105. Manhenke C, Orn S, Squire I, Radauceanu A, Alla F, Zannad F, Dickstein K: The prognostic value of circulating markers of collagen turnover after acute myocardial infarction. Int J Cardiol 2011, 150:277-282.

106. Thomas CV, Coker ML, Zellner JL, Handy JR, Crumbley AJ 3rd, Spinale FG: Increased matrix metalloproteinase activity and selective upregulation in LV myocardium from patients with end-stage dilated cardiomyopathy. Circulation 1998, 97:1708-1715.

107. Picard F, Brehm M, Fassbach M, Pelzer B, Scheuring S, Kury P, Strauer BE, Schwartzkopff B: Increased cardiac mRNA expression of matrix metalloproteinase-1 (MMP-1) and its inhibitor (TIMP-1) in DCM patients. Clin Res Cardiol 2006, 95:261-269.

108. Zervoudaki A, Economou E, Stefanadis C, Pitsavos C, Tsioufis K, Aggeli C, Vasiliadou K, Toutouza M, Toutouzas P: Plasma levels of active extracellular matrix metalloproteinases 2 and 9 in patients with essential hypertension before and after antihypertensive treatment. J Hum Hypertens 2003, 17:119-124

109. Tziakas DN, Chalikias GK, Parissis JT, Hatzinikolaou El, Papadopoulos ED, Tripsiannis GA, Papadopoulou EG, Tentes IK, Karas SM, Chatseras DI: Serum profiles of matrix metalloproteinases and their tissue inhibitor in patients with acute coronary syndromes. The effects of short-term atorvastatin administration. Int J Cardiol 2004, 94:269-277.

110. Webb CS, Bonnema DD, Ahmed SH, Leonardi AH, McClure CD, Clark LL, Stroud RE, Corn WC, Finklea L, Zile MR, Spinale FG: Specific temporal profile of matrix metalloproteinase release occurs in patients after myocardial infarction: relation to left ventricular remodeling. Circulation 2006, 114:1020-1027.

111. Kelly D, Cockerill G, Ng LL, Thompson M, Khan S, Samani NJ, Squire IB. Plasma matrix metalloproteinase- 9 and left ventricular remodelling after acute myocardial infarction in man: a prospective cohort study. Eur Heart J 2007, 28:711-718.

112. Wagner DR, Delagardelle C, Ernens I, Rouy D, Vaillant M, Beissel J: Matrix metalloproteinase-9 is a marker of heart failure after acute myocardial infarction. J Card Fail 2006, 12:66-72.

113. Vandervelde $S$, van Amerongen MJ, Tio RA, Petersen $A H$, van Luyn MJ Harmsen MC: Increased inflammatory response and neovascularization in reperfused vs. non-reperfused murine myocardial infarction. Cardiovasc Pathol 2006, 15:83-90.

114. Kobayashi K, Luo M, Zhang Y, Wilkes DC, Ge G, Grieskamp T, Yamada C, Liu TC, Huang G, Basson CT, Kisprt A, Geenspan DS, Sato TN: Secreted Frizzledrelated protein 2 is a procollagen $C$ proteinase enhancer with a role in fibrosis associated with myocardial infarction. Nat Cell Biol 2009, 11:46-55.

115. Duan J, Gherghe C, Liu D, Hamlett E, Srikantha L, Rodgers L, Regan JN, Rojas M, Willis M, Leask A, Majesky M, Deb A: Wnt1/betacatenin injury response activates the epicardium and cardiac fibroblasts to promote cardiac repair. EMBO J 2012, 31:429-442.

116. Jugdutt Bl: Limiting fibrosis after myocardial infarction. N Engl J Med 2009, 360:1567-1569.

117. Van Lint P, Libert C: Matrix metalloproteinase-8: cleavage can be decisive. Cytokine Growth Factor Rev 2006, 17:217-223.

118. Cuadrado E, Ortega L, Hernandez-Guillamon M, Penalba A, FernandezCadenas I, Rosell A, Montaner J: Tissue plasminogen activator (t-PA) promotes neutrophil degranulation and MMP-9 release. J Leukoc Biol 2008, 84:207-214.

119. Matsuda A, Itoh Y, Koshikawa N, Akizawa T, Yana I, Seiki M: Clusterin, an abundant serum factor, is a possible negative regulator of MT6-MMP/ MMP-25 produced by neutrophils. J Biol Chem 2003, 278:36350-36357.

120. Lambert JM, Lopez EF, Lindsey ML: Macrophage roles following myocardial infarction. Int J Cardiol 2008, 130:147-158.
121. Ammarguellat F, Larouche I, Schiffrin EL: Myocardial fibrosis in DOCA-salt hypertensive rats: effect of endothelin ET(A) receptor antagonism. Circulation 2001, 103:319-324

122. Ammarguellat FZ, Gannon PO, Amiri F, Schiffrin EL: Fibrosis, matrix metalloproteinases, and inflammation in the heart of DOCA-salt hypertensive rats: role of ET(A) receptors. Hypertension 2002, 39:679-684.

123. Koitabashi N, Danner T, Zaiman AL, Pinto YM, Rowell J, Mankowski J, Zhang D, Nakamura T, Takimoto E, Kass DA: Pivotal role of cardiomyocyte TGFbeta signaling in the murine pathological response to sustained pressure overload. J Clin Invest 2011, 121:2301-2312.

124. Cao L, Gardner DG: Natriuretic peptides inhibit DNA synthesis in cardiac fibroblasts. Hypertension 1995, 25:227-234.

125. Tsuruda T, Burnett JC Jr: Adrenomedullin: an autocrine/paracrine factor for cardiorenal protection. Circ Res 2002, 90:625-627.

126. Kapoun AM, Liang F, O'Young G, Damm DL, Quon D, White RT, Munson K, Lam A, Schreiner GF, Protter AA: B-type natriuretic peptide exerts broad functional opposition to transforming growth factor-beta in primary human cardiac fibroblasts: fibrosis, myofibroblast conversion, proliferation, and inflammation. Circ Res 2004, 94:453-461.

127. Watson CJ, Phelan D, Xu M, Collier P, Neary R, Smolenski A, Ledwidge M, McDonald K, Baugh J: Mechanical stretch up-regulates the B-type natriuretic peptide system in human cardiac fibroblasts: a possible defense against transforming growth factor-ss mediated fibrosis. Fibrogenesis Tissue Repair 2012, 5:9.

128. Knowles JW, Esposito G, Mao L, Hagaman JR, Fox JE, Smithies O, Rockman HA, Maeda N: Pressure-independent enhancement of cardiac hypertrophy in natriuretic peptide receptor A-deficient mice. J Clin Invest 2001, 107:975-984.

129. Kishimoto I, Rossi K, Garbers DL: A genetic model provides evidence that the receptor for atrial natriuretic peptide (guanylyl cyclase-A) inhibits cardiac ventricular myocyte hypertrophy. Proc Natl Acad Sci U S A 2001, 98:2703-2706

130. Vellaichamy E, Khurana ML, Fink J, Pandey KN: Involvement of the NF-KB/ matrix metalloproteinase pathway in cardiac fibrosis of mice lacking guanylyl cyclase/natriuretic peptide receptor A. J Biol Chem 2005, 280:19230-19242.

131. Morita E, Yasue H, Yoshimura M, Ogawa H, Jougasaki M, Matsumura T, Mukoyama M, Nakao K: Increased plasma levels of brain natriuretic peptide in patients with acute myocardial infarction. Circulation 1993, 88:82-91.

132. Saremi A, Gopal D, Maisel AS: Brain natriuretic peptide-guided therapy in the inpatient management of decompensated heart failure. Expert Rev Cardiovasc Ther 2012, 10:191-203.

133. Kandalam V, Basu R, Abraham T, Wang X, Awad A, Wang W, Lopaschuk GD, Maeda N, Oudit GY, Kassiri Z: Early activation of matrix metalloproteinases underlies the exacerbated systolic and diastolic dysfunction in mice lacking TIMP3 following myocardial infarction. Am J Physiol Heart Circ Physiol 2010, 299:H1012-H1023.

134. Kandalam V, Basu R, Moore L, Fan D, Wang X, Jaworski DM, Oudit GY, Kassiri Z: Lack of tissue inhibitor of metalloproteinases 2 leads to exacerbated left ventricular dysfunction and adverse extracellular matrix remodeling in response to biomechanical stress. Circulation 2011, 124:2094-2105.

135. Thireau J, Karam S, Fauconnier J, Roberge S, Cassan C, Cazorla O, Aimond F, Lacampagne A, Babuty D, Richard S: Functional evidence for an active role of B-type natriuretic peptide in cardiac remodeling and proarrhythmogenicity. Cardiovasc Res 2012, 95:59-68

136. Matsumura S, Iwanaga S, Mochizuki S, Okamoto H, Ogawa S, Okada Y: Targeted deletion or pharmacological inhibition of MMP-2 prevents cardiac rupture after myocardial infarction in mice. J Clin Invest 2005, 115:599-609.

137. Lindsey ML, Escobar GP, Mukherjee R, Goshorn DK, Sheats NJ, Bruce JA, Mains IM, Hendrick JK, Hewett KW, Gourdie RG, Matisian LM, Spinale FG: Matrix metalloproteinase-7 affects connexin-43 levels, electrical conduction, and survival after myocardial infarction. Circulation 2006, 113:2919-2928.

138. Heymans S, Luttun A, Nuyens D, Theilmeier G, Creemers E, Moons L, Dyspersin GD, Cleutjens JP, Shipley M, Angellilo A, Levi M, Nube O, Aker A, Keshet E, Lupu F, Herbert JM, Smits JF, Shapio SD, Baes M, Borgers M, Collen $D$, Daemen MJ, Carmeliet P: Inhibition of plasminogen activators or matrix metalloproteinases prevents cardiac rupture but impairs 
therapeutic angiogenesis and causes cardiac failure. Nat Med 1999, 5:1135-1142.

139. Ducharme A, Frantz S, Aikawa M, Rabkin E, Lindsey M, Rohde LE, Schoen FJ, Kelly RA, Werb Z, Libby P, Lee RT: Targeted deletion of matrix metalloproteinase-9 attenuates left ventricular enlargement and collagen accumulation after experimental myocardial infarction. J Clin Invest 2000, 106:55-62.

140. Creemers EE, Davis JN, Parkhurst AM, Leenders P, Dowdy KB, Hapke E, Hauet AM, Escobar PG, Cleutjens JP, Smits JF, Daemen MJ, Zile MR, Spinale FG: Deficiency of TIMP-1 exacerbates LV remodeling after myocardial infarction in mice. Am J Physiol Heart Circ Physiol 2003, 284:H364-H371.

141. Koskivirta I, Kassiri Z, Rahkonen O, Kiviranta R, Oudit GY, McKee TD, Kyto V, Saraste A, Jokinen E, Liu PP, Vuoio E, Khokha R: Mice with tissue inhibitor of metalloproteinases 4 (Timp4) deletion succumb to induced myocardial infarction but not to cardiac pressure overload. J Biol Chem 2010, 285:24487-24493.

142. Glass C, Singla DK: Overexpression of TIMP-1 in embryonic stem cells attenuates adverse cardiac remodeling following myocardial infarction. Cell Transplant 2012, Epub ahead of print, PMID:22449760.

143. Jayasankar V, Woo YJ, Bish LT, Pirolli TJ, Berry MF, Burdick J, Bhalla RC, Sharma RV, Gardner TJ, Sweeney HL: Inhibition of matrix metalloproteinase activity by TIMP-1 gene transfer effectively treats ischemic cardiomyopathy. Circulation 2004, 110:||180-||186.

144. Ramani R, Nilles K, Gibson G, Burkhead B, Mathier M, McNamara D, McTiernan CF: Tissue inhibitor of metalloproteinase-2 gene delivery ameliorates postinfarction cardiac remodeling. Clin Trans/ Sci 2011, 4:24-31.

145. Matsusaka H, Ide T, Matsushima S, Ikeuchi M, Kubota T, Sunagawa K, Kinugawa S, Tsutsui H: Targeted deletion of matrix metalloproteinase 2 ameliorates myocardial remodeling in mice with chronic pressure overload. Hypertension 2006, 47:711-717.

146. Heymans S, Lupu F, Terclavers S, Vanwetswinkel B, Herbert JM, Baker A, Collen D, Carmeliet P, Moons L: Loss or inhibition of UPA or MMP-9 attenuates LV remodeling and dysfunction after acute pressure overload in mice. Am J Pathol 2005, 166:15-25.

147. Kassiri Z, Oudit GY, Sanchez O, Dawood F, Mohammed FF, Nuttall RK, Edwards DR, Liu PP, Backx PH, Khokha R: Combination of tumor necrosis factor-alpha ablation and matrix metalloproteinase inhibition prevents heart failure after pressure overload in tissue inhibitor of metalloproteinase-3 knock-out mice. Circ Res 2005, 97:380-390.

148. Kassiri Z, Defamie V, Hariri M, Oudit GY, Anthwal S, Dawood F, Liu P, Khokha R: Simultaneous transforming growth factor beta-tumor necrosis factor activation and cross-talk cause aberrant remodeling response and myocardial fibrosis in Timp3-deficient heart. J Biol Chem 2009, 284:29893-29904.

doi:10.1186/1755-1536-5-15

Cite this article as: Fan et al:: Cardiac fibroblasts, fibrosis and extracellular matrix remodeling in heart disease. Fibrogenesis \& Tissue Repair 2012 5:15.

\section{Submit your next manuscript to BioMed Central and take full advantage of:}

- Convenient online submission

- Thorough peer review

- No space constraints or color figure charges

- Immediate publication on acceptance

- Inclusion in PubMed, CAS, Scopus and Google Scholar

- Research which is freely available for redistribution 